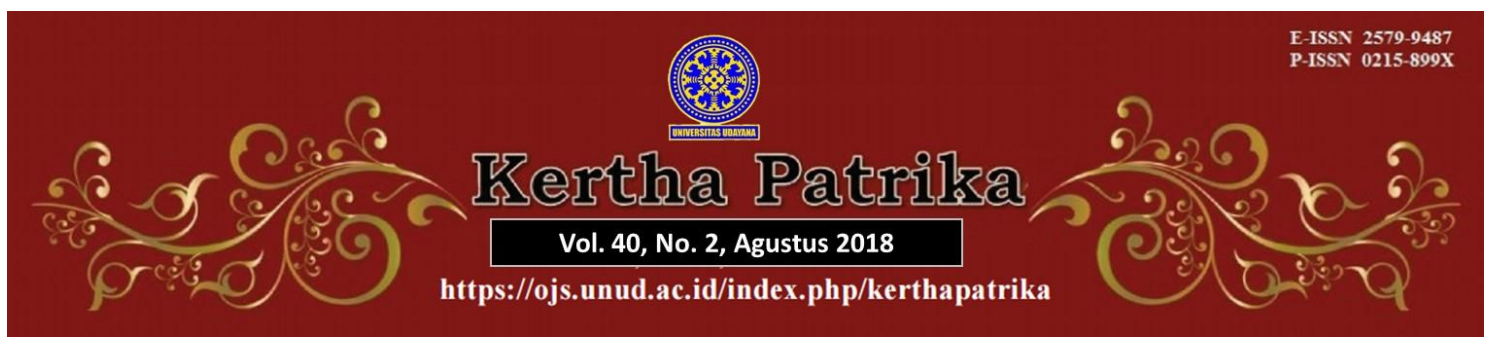

\title{
Pengaturan Perolehan Hak Milik Atas Tanah dalam Perkawinan Campuran
}

\author{
Gede Ode Angga Pratama ${ }^{1}$ \\ ${ }^{1}$ Kantor Notaris/PPAT I Gusti Ngurah Agung Diatmika, SH., \\ E-mail: odelasardo@gmail.com
}

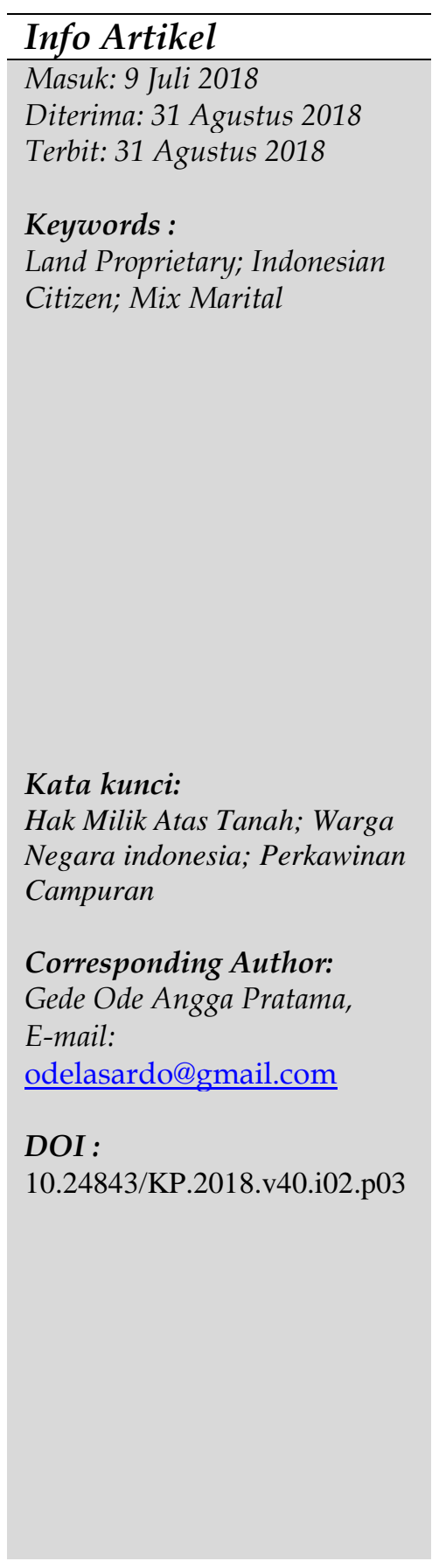

\begin{abstract}
This article conflict of norm (conflicten van normen) between Article 3 of Government Regulation Year 2015 No. 103 with Article 21 paragraph (1) and (3) Act Year 1960 No. 5. The legal problems are: (1) Is the land proprietary acquisition by the Indonesian citizen in mix marital with or without pre-nuptial agreement is accordance to the principle of nationality and (2) What is the implication of the proprietary ownership. The type of this research method is normative legal research. This study applied statue approach, conseptual approach, and case approach. The legal resources used are primary legal resources and secondary legal resources collected by snowball method. Legal resources analysis used description, comparison, evaluation, and argumentation technique. The results are: (1) The land proprietary acquisiton of mix marital with or without prenuptial agreement is accordance to the principle of nationality as long the Indonesian citizen in their nationality. (2) The implication of land proprietary ownership is still exis as long owned by the Indonesian citizen.
\end{abstract}

Abstrak
Artikel ini membahas adanya konlifk aturan (conflicten van
normen) antara Pasal 3 PP No. 103 Tahun 2015 dengan
Pasal 21 ayat (1) dan (3) UU No. 5 Tahun 1960. Rumusan
masalah dalam penelitian ini adalah (1) Apakah
pengaturan perolehan hak milik atas tanah dalam
perkawinan campuran dengan atau tanpa perjanjian kawin
sesuai dengan asas nasionalitas serta (2) Apakah akibat
hukum dari perolehan tersebut. Jenis penelitian ini adalah
penelitian hukum normatif. Pendekatan dalam penelitian
ini adalah pendekatan Perundang-undangan, pendekatan
konsep hukum, dan pendekatan. Sumber bahan hukum
yang digunakan adalah bahan hukum primer dan bahan
hukum sekunder. Teknik pengumpulan bahan hukum
melalui snowball theory. Teknik analisis yang digunakan
adalah deskripsi, komparisi, evaluasi, dan argumentasi.
Hasil penelitian ini adalah (1) Pengaturan perolehan hak
milik atas tanah dalam perkawinan campuran dengan atau
tanpa perjanjian kawin sesuai dengan asas nasionalitas
sepanjang WNI mempertahankan kewarganegaraannya.
(2) Sementara itu akibat hukum perolehan hak milik dalam
perkawinan campuran dengan atau tanpa perjanjian kawin


adalah tidak hapus karena hukum selama dimiliki WNI.

\section{Pendahuluan}

Asas nasionalitas dalam Pasal 9 ayat (1) jo. Pasal 21 ayat (1) Undang-Undang No. 5 Tahun 1960 tentang Peraturan Dasar Pokok-Pokok Agraria menentukan hanya Warga Negara Indonesia yang dapat mempunyai hak milik atas tanah. WNI dalam perkawinan campuran dengan atau tanpa perjanjian kawin tetap dapat memperoleh hak milik sepanjang ia mempertahankan kewarganegaraan Indonesianya. Jika hak milik beralih ke Warga Negara Asing, salah satunya karena pewarisan percampuran harta karena perkawinan telah diantisipasi oleh Pasal 21 ayat (3) UU No. 5 Tahun 1960. Perjanjian kawin tidak dapat memperoleh hak milik. ${ }^{1}$ Problematika hukum yang akan dibahas dalam penelitian ini adalah: Pertama, adanya pemahaman yang keliru terhadap Pasal 21 ayat (3) $)^{2}$ dan Pasal 26 ayat (2) UU No. 5 Tahun 1960 serta Pasal 35 ayat (1) UU No. 1 Tahun 1974. ${ }^{3}$ Kedua, adanya konflik aturan (convlicten van normen) secara vertikal antara Pasal 3 Peraturan Pemerintah Republik Indonesia Nomor 103 Tahun 2015 Tentangg Pemilikan Rumah Tempat Tinggal Atau Hunian Oleh Orang Asing Yang Berkedudukan Di Indonesia dengan Pasal 21 ayat (1) dan (3) UU No. 5 Tahun 1960. Terakhir, adanya Putusan MK No. 69/PUU/2015 mengenai pembuatan perjanjian kawin dalam konteks perolehan hak milik dalam perkawinan campuran.

Perolehan hak milik dalam perkawinan campuran dipahami harus dengan perjanjian kawin dan secara normatif oleh Pasal 3 PP No. 103 Tahun 2015 ditentukan dengan perjanjian pemisahan harta, hal ini akan berpengaruh terhadap hak milik yang diperoleh WNI dalam perkawinan campuran tanpa perjanjian kawin. Problematika hukumnya adalah: Pertama, hak milik dianggap hapus karena hukum sesuai Pasal 27 huruf a angka 4 UU No. 5 Tahun $1960 .{ }^{4}$ Kedua, karena sudah terlanjur dipahami hapus, hak milik yang ingin dialihkan kepada pihak lain atau dibebani hak tanggungan tidak dapat dilakukan sebagaimana mestinya. Ketiga, karena hak milik merupakan harta bersama diperlukan persetujuan pasangan WNA ketika ingin dialihkan atau dibebankan. Identitas WNA yang tertera dalam akta Pejabat Pembuat Akta Tanah (PPAT) akan dikembalikan oleh Badan Pertanahan Nasional ketika akta didaftarkan.

Mengingat peliknya problematika hukum ini, baik dalam tataran teoritis maupun praktis maka penelitian ini sangat penting untuk dilakukan. Rumusan masalah dalam

\footnotetext{
${ }^{1}$ Lihat Putusan MK No. 69/PUU-XIII/2015, Tertanggal 27-10-2016, h. 92.

2 Lihat Irma Devita Purnamasari, 2013, Kicauan Praktisi @IrmaDevitaCom: Seputar Pertanahan, PT. Mizan Putaka, Bandung (selanjutnya disebut Irma Devita Purnamasari I), h. 20.

${ }^{3}$ Lihat Sonny Dewi Judiasih, 2015, Harta Benda Perkawinan: Kajian Terhadap Kesetaraan Hak dan Kedudukan Suami dan Isteri Atas Kepemilikan harta Dalam Perkawinan, PT. Refika Aditama, Bandung, h. 23.

4 Alwesius, 2016, "Pembuatan Akta Perjanjian Perkawinan Pasca Putusan Mahkamah Konstitusi Nomor 69/PUU-XIII/2015 Serta Akibat Hukumnya Terhadap Perolehan, Penjaminan, dan Kepemilikan Tanah Oleh Pasangan Kawin Campur", Makalah Pada Seminar Terbatas Dengan Tema: Implementasi Putusan Mahkamah Konstitusi Tentang Perkawinan Campur, Kaitannya dengan Pemilikan Properti di Indonesia dan Praktek Notaris-PPAT, Diselenggarakan Oleh Pengurus Wilayah Ikatan Notaris Indonesia (INI) dan Ikatan Pejabat Pembuat Akta Tanah (IPPAT) Bali, Denpasar, h. 28.
} 
penelitian ini sebagai berikut: (1) Apakah pengaturan perolehan hak milik atas tanah dalam perkawinan campuran dengan atau tanpa perjanjian kawin sesuai dengan asas nasionalitas? (2) Apakah akibat hukum perolehan hak milik atas tanah dalam perkawinan campuran dengan atau tanpa perjanjian kawin?

\section{Metode Penelitian}

Jenis penelitian ini adalah penelitian hukum normatif. Pendekatan yang digunakan untuk menganalisis permasalahan ini meliputi pendekatan perundang-undangan (statue approach), pendekatan konsep hukum (conceptual approach), dan pendekatan kasus (case approach). Dengan pendekatan Perundang-undangan (Statute approach), ditelusuri Peraturan Perundang-undangan mengenai masalah tersebut. Dengan Pendekatan konsep hukum (Conceptual Approach), ${ }^{5}$ yang lebih esensial dilakukan dengan penelusuran buku-buku hukum. Pendekatan kasus (Case Approach) dilakukan dengan menganalisis Putusan MK No. 69/PUU-XIII/2015. Bahan hukum yang digunakan dalam penelitian ini adalah bahan hukum primer dan sekunder. Teknik analisis yang digunakan dalam penelitian adalah deskripsi, komparasi, evaluasi, dan argumentasi.

\section{Hasil dan Pembahasan}

\subsection{Problematika Hukum Perolehan Hak Milik Atas Dalam Perkawinan Campuran Tanpa Perjanjian Kawin}

Problematika hukum yang diangkat dalamartikel ini adalah berlakunya Pasal 35 ayat (1) UU No. 1 Tahun 1974 dalam perkawinan campuran dimana setengah bagian hak milik atas tanahdipahami menjadi milik WNA. ${ }^{6}$ Setengah bagian yang dipahami menjadi milik WNA kemudian dikualifikasikan dalam Pasal 26 ayat (2) UU No. 5 Tahun 1960.7 Adapun yang perlu dipahami adalah tanah selain berdimensi hukum juga bernilai ekonomis. ${ }^{8}$ Dari segi hukum menitikberatkan pada aturan, sedangkan dari segi ekonomi terdapat nilai ekonomis dari tanah tersebut. ${ }^{9}$ Dari segi aturan berdasarkan Pasal 9 ayat (1) jo. Pasal 21 ayat (1) UU No. 5 Tahun 1960 telah jelas dan tegas diberikan batasan hanya WNI yang dapat mempunyai hak milik. Hak milik yang menjadi harta bersama dalam perkawinan campuran sebagaimana dimaksud Pasal 35 ayat (1) UU No. 1 Tahun 1974, setengah bagian yang menjadi milik WNA adalah hak atau nilai ekonomisnya.

Hak milik yang menjadi harta bersama dalam perkawinan campuran juga tidak dapat dikualifikasikan sebagai upaya secara tidak langsung memindahkan hak milik kepada

\footnotetext{
${ }^{5}$ Ida Bagus Wyasa Putra, 2015, “Analisis Konteks dalam Epistemologi Ilmu Hukum: Suatu Model Penerapan dalam Pengaturan Perdagangan Jasa Pariwisata Internasional Indonesia", Orasi Ilmiah Pidato Pengukuhan Jabatan Guru Besar Tetap Dalam Bidang Ilmu Hukum (Hukum Ekonomi Internasional) Pada Fakultas Hukum Universitas Udayana, Jimbaran (selanjutnya disebut Ida Bagus Wyasa Putra IV), h. 13.

${ }^{6}$ Lihat Sonny Dewi Judiasih, Loc. Cit. Lihat juga Rosa Agustina, 2012, "Beberapa Catatan Tentang Hukum Perkawinan di Indonesia, dalam Hukum Tentang Orang, Hukum Keluarga, dan Hukum Waris di Belanda dan Indonesia", Pustaka Larasan, Denpasar, h. 144.

${ }^{7}$ Alwesius, Op. Cit., h. 9.

8 Maria S.W. Sumardjono, 2009, Tanah Dalam Perspektif Hak Ekonomi Sosial dan Budaya, Kompas, Jakarta (selanjutnya disebut Maria S.W. Sumardjono I), h. 134.

9 Damanhuri, 2012, Seg-segi Hukum Perjanjian Perkawinan Harta Bersama, CV. Mandar Maju, Bandung, h. 28.
} 
pasangan kawin yang WNA sebagimana dimaksud Pasal 26 ayat (2) UU No. 5 Tahun 1960. Perbuatan secara tidak langsung memindahkan hak milik kepada orang asing adalah melalui perjanjian nominee. Dalam perkawinan yang ditekankan adalah aspek formal.10 Sepanjang perkawinan campuran telah memenuhi syarat materiil dan formil dalam UU No. 1 Tahun 1974, perolehan harta benda berupa hak milik atas tanah adalah sah dan sesuai UU No. 5 Tahun 1960. Jika terjadi perceraian, WNA mendapat setengah bagian nilai atau hak ekonomis dari hak milik tersebut. ${ }^{11}$ Berbeda jika perkawinan campuran dilakukan secara siri, jika terjadi perceraian hak milik yang menjadi harta bersama sepenuhnya milik WNI.

\subsection{Pengaturan Perolehan Hak Milik Atas Tanah Bagi Warga Negara Indonesia Dalam Perkawinan Campuran Dengan Atau Tanpa Perjanjian Kawin}

Pertama perlu diluruskan pemahaman yang keliru sebagaimana selama ini dipahami oleh akademisi diantaranya A.P. Parlindungan ${ }^{12}$ dan Gusti Ayu Ketut Rachmi ${ }^{13}$ serta praktisi Notaris/PPAT Herlien Budiono ${ }^{14}$ dan Irma Devita ${ }^{15}$ terhadap Pasal 21 ayat (3) UU No. 5 Tahun 1960. Seringkali Pasal 21 ayat (3) dipahami WNA memperoleh hak milik atas tanah seketika diperoleh WNI dalam perkawinan campuran tanpa perjanjian kawin.

Sesuai Penjelasan Pasal 21 ayat (3) ditentukan dua cara orang asing memperoleh hak milik tanpa melakukan tindakan positip (garis bawah dari penulis) yang sengaja ditujukan pada terjadinya pada peralihan hak itu. Tepat apa yang dikemukakan Herri Yudhianto Putro dalam tesisnya bahwa dua cara WNA memperoleh hak milik tanpa melakukan tindakan positip atau secara pasif adalah:16 (1) karena pewarisan tanpa wasiat dan (2) karena pewarisanpercampuran harta karena perkawinan. Konstruksi hukum yang benar adalah WNA memperoleh hak milik pada saat pasangan kawin yang WNI meninggal dunia, yaitu WNA memperoleh hak milik baik karena pewarisan tanpa wasitat atau pewarisan percampuran harta karena perkawinan. Pada saat hak

10 Djaja S. Melia, (2015), Perkembangan Hukum Perdata Tentang Orang dan Keluarga, Nuansa Aulia, Bandung, h. 54.

11 Anita D.A. Kolopaking, 2013, Penyelundupan Hukum Kepemilikan Hak Milik Atas Tanah di Indonesia, PT. Alumni, Bandung, h. 172.

12 Lihat A.P. Parlindungan, 2008, Komentar Atas Undang-undang Pokok Agraria, Cet. IX, CV. Mandar Maju, Bandung, h. 143.

13 Lihat I Gusti Ayu Ketut Rachmi Handayani, (2017), “Kewarganegaraan dan Warisan Pada Perkawinan Campuran", Makalah Pada Seminar: Keragaman Hukum Waris Di Indonesia, Problematika Dan Solusinya Dalam Pembuatan Surat/Akta Keterangan Hak Waris, Diselenggarakan Oleh Pengurus Daerah Ikatan Notaris Indonesia (INI) Sukoharjo dengan "Pioneer" Study Club Notary dan didukung oleh Fakultas Hukum Universitas Sebelas Maret Surakarta, Sukoharjo, h. 8-10.

14 Lihat Herlien Budiono, 2016, Kumpulan Tulisan Hukum Perdata di Bidang Kenotariatan: Buku Kesatu, PT. Citra Aditya Bakti, Bandung, h. 176-177.

15 Irma Devita Purnamasari I, Loc. Cit. Dalam tulisannya yang lain Irma Devita juga mengemukakan hal yang sama. Lihat juga Irma Devita Purnamasari, 2015, Panduan Lengkap Hukum Praktis Populer: Kiat-kiat Cerdas, Mudah, dan Bijak Memahami Masalah Hukum Waris, Cet. II, PT. Mizan Pustaka, Bandung (selanjutnya disebut Irma Devita Purnamasari II), h. 166-170.

16 Herri Yudhianto Putro, (2013), "Kewenangan Bertindak Warga Negara Indonesia Dalam Perkawinan Campuran Atas Kepemilikan Hak Milik Atas Tanah", Tesis Program Studi Magister Kenotariatan, Fakultas Hukum Universitas Diponegoro, Semarang, h. 120. 
milik diperoleh WNI dalam perkawinan campuran tanpa perjanjian kawin. hak milik tidak beralih ke WNA.

Dari uraian tersebut dapat dipahami bahwa WNI dalam perkawinan campuran dengan atau tanpa perjanijan kawin dapat memperoleh hak milik. Hak milik yang diperoleh tanpa perjanjian kawin beralih ketika WNI meninggal dunia atau dengan kata lain WNA memperoleh hak milik adalah karena pewarisan percampuran harta karena perkawinan.

Secara filosofis hubungan antara tanah dengan bangsa Indonesia bersifat abadi. ${ }^{17}$ Dengan batasan itu Maria S.W. Sumardjono mengemukakan hanya WNI yang dapat mempunyai hubungan hukum sepenuhnya dengan hak milik. ${ }^{18}$ Makna "sepenuhnya" menurut $\mathrm{H}$. Martin Roestamy memiliki arti yang sangat dalam dan luas antara hubungan subjek hukum dengan tanah. ${ }^{19}$ Sesuai batasan itu pula Eman Ramelan mengemukakan tidak mungkin WNA mempunyai hak milik. ${ }^{20}$ Menurut John Locke tanah merupakan hak kodrati bagi setiap makhluk hidup dan merupakan konsep keadilan yang diberikan oleh Tuhan Yang Maha Esa. ${ }^{21}$ Artinya setiap WNI berhak memperoleh hak milik. Ida Bagus Wyasa Putra memberikan batasan sepanjang WNI mempertahankan kewarganegaraan dalam perkawinan campuran, perolehan hak milik dijamin oleh Konstitusi ${ }^{22}$ dan Undang-undang. ${ }^{23}$ Secara konseptual hak milik dapat diperoleh WNI yang; tidak kawin, kawin dengan WNI, atau kawin dengan WNA dengan atau tanpa perjanjian kawin. Perolehan hak milik dalam perkawinan campuran dengan atau tanpa perjanjian kawin sesuai dengan asas nasionalitas sepanjang WNI mempertahankan kewarganegaraannya. ${ }^{24}$ Hak milik yang beralih ke WNA dalam perkawinan campuran, salah satunya karena pewarisan percampuran harta juga telah diantisipasi oleh Pasal 21 ayat (3) untuk dilepaskan dengan limitasi sebelum satu tahun.

${ }^{17}$ Lihat Pasal 1 ayat (3), Pasal 9 ayat (1), dan Pasal 21 ayat (1) UU No. 5 Tahun 1960.

18 Maria S.W. Sumardjono, 2008, Alternatif Kebijakan Pengaturan hak Atas Tanah Beserta Bangunan Bagi Warga Negara Asing dan Badan Hukum Asing, Cet. II, Kompas, Jakarta (selanjutnya disebut Maria S.W. Sumardjono II), h. 102.

${ }^{19}$ H. Martin Roestamy, Konsep-konsep Hukum Properti Bagi Asing (Dihubungkan dengan Hukum Pertanahan), PT. Alumni, Bandung, h. 19.

${ }^{20}$ Eman Ramelan, et. al., 2015, Problematika Hukum Hak Milik Atas Satuan Rumah Susun dalam Pembebanan dan Peralihan Hak Atas Tanah, Cet. II, Aswaja Pressindo, Yogyakarta selanjutnya disebut Eman ramelan I), h. 40 dan 77.

${ }^{21}$ Widhi Handoko, 2014, Kebijakan Hukum Pertanahan: Sebuah Refleksi Keadilan Hukum Progresif, Thafa Media, Yogyakarta, h. 176.

22 Pasal 28H ayat (4) UUD 1945 menentukan "Setiap orang berhak mempunyai hak miliki dan hak milik tersebut tidak boleh diambil alih secara sewenang-wenang oleh siapapun".

${ }^{23}$ Ida Bagus Wyasa Putra, 2016, "Perjanjian Kawin Dalam Perkawinan Campuran Paska Putusa MK No. 69/PUU-XIII/2015", Makalah Pada: Konfrensi Pengurus Daerah (Konferda) Ikatan Notaris Indonesia (INI) Badung, Bali (selanjutnya disebut Ida Bagus Wyasa Putra V), h. 3.

${ }^{24}$ Perempuan atau laki-laki dalam perkawinan campuran jika ingin tetap menjadi WNI dapat mengajukan surat pernyataan mengenai keinginannya kepada Pejabat atau Perwakilan RI yang wilayahnya meliputi tempat tinggal perempuan atau laki-laki tersebut, kecuali pengajuan tersebut mengakibatkan kewarganegaraan ganda. Lihat Pasal 26 UU No. 12 Tahun 2006. 
Kehadiran Pasal 3 PP No. 103 Tahun 2015 yang pada intiya menentukan WNI dalam perkawinan campuran dapat memiliki hak atas tanah yang dibuktikan dengan perjanjian pemisahan harta yang dibuat dengan akta Notaris, telah menimbulkan konflik aturan (conflicten van normen) dengan Pasal 21 ayat (1) dan (3) UU No. 5 Tahun 1960. Dikaji berdasarkan teori Perjenjangan Norma/Stuffenbau Theory dari Hans Kelsen/Hans Nawiaasky dan asas Lex Superior Derogate Lex Inferior Pasal 21 ayat (1) dan (3) UU No. 5 Tahun 1960 mengesampingkan Pasal 3 PP No. 103 Tahun 2015. Untuk itu harus dilakukan sinkronisasi aturan ${ }^{25}$ yaitu dengan menghapus ketentuan Pasal 3 PP No. 103 Tahun 2015.26 Perkumpulan Masyarakat Perkawinan Campuran (PerCa) Indonesia juga sedang melakukan uji materi Pasal tersebut di MA. ${ }^{27}$ MA berdasarkan kewenangannya ${ }^{28}$ harus mengambil sikap terhadap Pasal tersebut.

\subsection{Perjanjian Kawin Pasca Putusan Mahkamah Konstitusi Nomor 69/PUU- XIII/2015 Dalam Konteks Perolehan Hak Milik Atas Tanah Dalam Perkawinan Campuran}

Berdasarkan pertimbangan hukum dalam Putusan MK No.69/PUU-XIII/2015, MK nampaknya juga berpandangan perolehan hak milik atas tanah dalam perkawinan campuran harus dengan perjanjian kawin. I Dewa Gede Palguna memberikan batasan perolehan hak milik bagi WNI dalam perkawinan campuran, yaitu:29

1. Ia tetap mempertahankan kewarganegaraan Indonesianya;

2. Membuat perjanjian kawin, yang dapat dibuat kapan saja selama dalam perkawinan sesuai dengan kesepakatan mereka, yang berisi penegasan pisah harta.

Dapat dipahami bahwa Putusan tersebut pada hakikatnya ingin melindungi kepentingan WNI untuk memperoleh hak milik dalam perkawinan campuran. Meski begitu ada beberapa problematika hukum terhadap Putusan tersebut. Pertama perjanjian kawin dapat dibuat selama perkawinan. Pembuatan ini menimbulkan ketidakpastian hukum terhadap harta benda yang telah diperoleh sebelumnya. ${ }^{30}$ Sesuai konstruksi hukumnya, perjanjian kawin sudah tepat dibuat sebelum atau pada

25 Sinkronisasi aturan dilakukan dalam hal terjadi tumpang tindih aturan atas suatu objek tertentu. Lihat Achmad Sodiki, 2013, Politik Hukum Agraria, Konstitusi Press (Konpress), Jakarta, h. 44.

26 Maria Farida Indrati S., 2007, Ilmu Perundang-undangan 2: Proses dan Teknik Penyusunan, Kanisius, Yogyakarta (selanjutnya disebut Maria Farida Indrati S. II), h. 179.

27 Pasal ini sedang diajukan uji materiil ke MA. Lihat HukumOnline.com: PP Hunian Orang Asing: MA Diminta Batalkan Klausula "Perjanjian Kawin", Published 10-10-2016, diakses tanggal 13-03-2017 melalui twitter.

${ }^{28}$ Lihat Pasal 9 ayat (2) UU No. 11 Tahun 2011. Kemudian lihat juga Pasal 31 ayat (1) dan (2) UU No. 5 Tahun 2004.

29 I Dewa Gede Palguna, 2016, "Perkawinan Campuran dan Pemilikan Hak Atas Tanah PascaPutusan Mahkamah Konstitusi Nomor 69/PUU-XIII/2015", Makalah Pada Seminar Terbatas Dengan Tema: Implementasi Putusan Mahkamah Konstitusi tentang Perkawinan Campur, Kaitannya dengan Pemilikan Properti di Indonesia dan Praktek Notaris-PPAT, Diselenggarakan Oleh Pengurus Wilayah Ikatan Notaris Indonesia (INI) dan Ikatan Pejabat Pembuat Akta Tanah (IPPAT) Bali, Denpasar, h. 8.

30 M. Isnaeni, 2016, "Problematika Perjanjian Kawin Pasca Putusan Mahkamah Konstitusi No. 69/PUU-XIII/2015", Makalah Pada Seminar: Problematika Perjanjian Kawin Pasca Putusan Mahkamah Konstitusi No. 69/PUU-XIII/2015", Program Studi Magister Kenotariatan, Fakultas Hukum Universitas Airlangga, Surabaya (selanjutnya disebut M. Isnaeni I), h. 19. 
saat perkawinan sebagaimana ditentukan sebelumnya dalam Pasal 29 ayat (1) UU No. 1 Tahun 1974. Problematika hukum lainnya adalah perjanjian kawin disahkan oleh Notaris. ${ }^{31}$ Berdasarkan Pasal 1 angka 1 jo. Pasal 15 UU No. 2 Tahun 2014, Notaris tidak mempunyai kewenangan itu. Kewenangan itu ada di ranah administrasi yaitu KUA atau Catatan Sipil. Meskipun sekarang WNI dalam perkawinan campuran yang sebelumnya tidak mempunyai perjanjian kawin dapat membuat perjanjian kawin dalam konteks memperoleh hak milik, sejatinya tidak diperlukan perjanjian kawin untuk perolehan tersebut.

\subsection{Akibat Hukum Hak Milik Atas Tanah Yang Diperoleh Warga Negara Indonesia Dalam Perkawinan Campuran Dengan Atau Tanpa Perjanjian Kawin}

Akibat hukum hak milik yang diperolah WNI dalam perkawinan campuran tanpa perjanjian kawin oleh beberapa Pakar Hukum Kenotariatan dipahami hapus karena hukum terhitung satu tahun sejak perolehan itu. ${ }^{32}$ Sesungguhnya masih banyak yang berpandangan demikian. ${ }^{33}$ Persoalan ini memang tidak bisa dilepaskan dari pemahaman yang keliru terhadap Pasal 21 ayat (3) UU No. 5 Tahun 1960 ditambah lagi adanya Pasal 3 PP No. 103 Tahun 2015.

Tadi telah diuraikan Pasal 21 ayat (3) bahwa hak milik beralih ke WNA dalam perkawinan campuran ketika terjadi pewarisan percampuran harta karena perkawinan. Hak milik yang diperoleh WNI dalam perkawinan campuran tanpa perjanjian kawin tidak beralih ke WNA. Telah diuraikan pula Pasal 21 ayat (1) dan (3) UU No. 5 tahun 1960 mengesampingkan Pasal 3 PP No. 103 Tahun 2015.

Hak milik yang diperoleh WNI dalam perkawinan campuran dengan atau tanpa perjanjian kawin tidak hapus selama dimilikinya. Sesuai Pasal 27 huruf a angka 4, hak milik hapus karena beralih ke orang asing dan tidak dilepaskan dalam jangka waktu satu tahun. kembali lagi, mengenai momentum beralihnya hak milik ke WNA kuncinya adalah Pasal 21 ayat (3) UU No. 5 Tahun 1960. John Locke menyatakan "Ownership of property is a natural right and that the purpose of Government is to protect and preserve natural property right" ${ }^{34}$ Artinya selama masih dimiliki WNI hak milik tidak hapus karena hukum.

\subsection{Peralihan Hak Terhadap Hak Milik Atas Tanah Yang Diperoleh Warga Negara} Indonesia Dalam Perkawinan Campuran Dengan Atau Tanpa Perjanjian Kawin

Berdasarkan Pasal 20 ayat (2) UU No. 5 Tahun 1960 ditentukan “Hak Milik dapat beralih atau dialihkan". Problematika hukumnya adalah hak milik atas tanah yang diperoleh WNI dalam perkawinan campuran tanpa perjanjian kawin dipahami hapus

31 Agus Yudha Hernoko, 2016, “Quo Vadis Perlindungan Hukum Bagi Pihak Ketiga Dalam Perjanjian Perkawinan (Problematika Hukum Pasca Putusan MK Nomor 69/PUUXIII/2015)", Makalah Pada Seminar: Problematika Perjanjian Kawin Pasca Putusan Mahkamah Konstitusi No. 69/PUU-XIII/2015, Program Studi Magister Kenotariatan, Fakultas Hukum Universitas Airlangga, Surabaya, h. 10.

32 Lihat Alwesius, Op. Cit., hal. 28. Lihat juga Habib Adjie, 2016, Kompilasi Persoalan Hukum Dalam Praktek Notaris dan PPAT (Kapita Selekta Notaris \& PPAT), Jilid 1, Indonesia Notary Community (INC), h. 518.

33 Lihat diantaranya Eddy Nyoman Winarta, (2017), "Hak Pakai Atas Rumah Hunian Warga Negara Asing Dalam Perkawinan Campuran", Tesis Program Magister Kenotariatan, Fakultas Hukum Universitas Udayana, Denpasar, h. 202.

${ }^{34}$ Lloyd's, 1985, Introduciton to Jusrisprudence, Stevens and Sons Ltd, London, h. 158. 
sehingga ketika hak milik ingin dialihkan atau dijual kepada pihak lain disarankan dibuat akta pelepasan hak $^{35}$ terlebih dahulu. ${ }^{36}$ Yang lebih tidak rasional adalah Notaris/PPAT menyarankan WNI tersebut membuat KTP palsu yang menyatakan tidak kawin. ${ }^{37}$

Tadi telah diuraikan hak milik yang diperoleh WNI dalam perkawinan campuran dengan atau tanpa perjanjian kawin adalah tidak hapus. Secara konseptual hak milik yang dimiliki WNI tersebut dapat dialihkan/dijual kepada pihak lain. Dalam peralihannya, konstruksi hukum yang benar adalah langsung dibuat AJB di hadapan PPAT tanpa perlu dibuat akta pelepasan hak. Akta pelepasan hak dibuat ketika hak milik dimiliki oleh subjek hukum yang tidak berhak mempunyai hak milik. Notaris/PPAT juga tidak perlu menyarankan WNI dalam perkawinan campuran tanpa perjanjian kawin untuk membuat KTP palsu.

Akta PPAT memang berfungsi sebagai alat pendaftaran. Dalam prakteknya AJB yang didalamnya tertera identitas pasangan kawin yang WNA, ketika didaftarkan di BPN, AJB tersebut dikembalikan karena BPN berpandangan hak tersebut melekat pada WNA. ${ }^{38}$ BPN sebagai Pejabat atau Badan Tata Usaha Negara tidak perlu mencampuri urusan keperdataan orang per orang. ${ }^{39}$ Identitas pasangan kawin WNA yang tertera dalam AJB kapasitasnya adalah memberikan persetujuan sebagaimana ditentukan Pasal 36 ayat (1) UU No. 1 Tahun 1974, bukan sebagai pemegang hak sebagaimana disampaikan BPN.

\subsection{Pembebanan Hak Tanggungan Terhadap Hak Milik Atas Tanah Yang Diperoleh Warga Negara Indonesia Dalam Perkawinan Campuran Dengan Atau Tanpa Perjanjian Kawin}

Berdasarkan Pasal 25 UU No. 5 Tahun 1960 ditentukan "Hak milik dapat dijadikan jaminan utang dengan dibebani Hak Tanggungan“. Problematika hukumnya ketika hak milik ingin dibebankan hampir sama dengan peralihannya, yaitu dibuat akta pelepasan hak terlebih dahulu baru dimohonkan kembali.

Tadi telah dikemukakan bahwa hak milik tidak beralih ke pasangan WNA dan hapus karena hukum. Secara teoritis dan konseptual hak milik yang dimiliki WNI dapat dibebani hak tanggungan. Dalam praktek pembuatan perjanjian kredit dan SKMHT/APHT akan ditolak Pihak Bank atau Notaris/PPAT ketika hak milik yang ingin dijaminkan dimiliki WNI dalam perkawinan campuran tanpa perjanjian kawin.

35 Pelepasan hak dibuat salah satunya karena orang tersebut tidak berhak menjadi subjek hukum pemegang hak milik. Lihat lebih lanjut Eman Ramelan, et. al., 2015, Perlindungan Hukum bagi Konsumen Pembeli Satuan Rumah Susun/Strata Title/Apartemen, Aswaja Pressindo, Yogyakarta (selanjutnya disebut Eman Ramelan II), h. 123.

36 Alwesius, Op. Cit., h. 27.

37 I Made Januartayasa, "Pelepasan Hak milik Atas Tanah Yang Diperoleh Suami Istri Dalam Perkawinan Campuran Di Kabupaten Badung", Tesis Program Studi Magister Kenotariatan, Fakultas Hukum Universitas Brawijaya, Malang, h. 61-63.

38 Lihat kembali I Made Januartayasa, Ibid.

39 Habib Adjie, 2014, Merajut Pemikiran Dalam Dunia Notaris E PPAT, Cet. II, PT. Citra Aditya Bakti, Bandung (selanjutnya disebut Habib Adjie II), h. 96. 
Alasannya, pemasangan hak tanggungan atasnya akan terancam gugur bersamaan dengan hapusnya hak milik. 40

Pemasangan hak tanggungan di atas hak milik tersebut tidak akan gugur karena hak milik tidak hapus selama dimiliki WNI. Dalam pembebanannya identitas pasangan kawin yang WNA akan tertera di SKMHT/APHT dalam kapasitasnya memberi persetujuan. APHT yang telah dibuat dapat didaftar di BPN untuk memenuhi asas publisitas ${ }^{41}$ dan menentukan posisi kreditur sebagai kreditur preferen. Ini perlu digaris bawahi, merujuk pada kasus AJB di atas, sekalipun APHT dapat dibuat di hadapan PPAT namun tidak dapat didaftarkan di BPN. Yang penting diperhatikan adalah berdasarkan Pasal 13 ayat (5) UU No. 4 Tahun 1996 ditentukan hak tanggungan lahir saat didaftarkan. APHT yang tidak dapat didaftarkan di BPN menyebabkan posisi kreditur sebagai kreditur konkuren jika debitur wanprestasi. Akan lebih rumit jika uang telah diberikan bank kepada debitur.

\section{Kesimpulan}

1. Pengaturan perolehan hak milik atas tanah dalam perkawinan campuran dengan atau tanpa perjanjian kawin sesuai dengan asas nasionalitas sepanjang WNI mempertahankan kewarganegaraannya. Hak milik yang diperoleh WNI dalam perkawinan campuran tanpa perjanjian kawin tidak beralih ke WNA dan baru beralih karena pewarisan percampuran harta karena perkawinan sebagaimana dimaksud Pasal 21 ayat (3) UU No. 5 Tahun 1960. Sesuai teori Perjenjangan Norma/Stufenbau Theory dan asas Lex Superior Derogate Lex Inferior Pasal 21 ayat (1) dan (3) UU No. 5 Tahun 1960 mengesampingkan Pasal 3 PP No. 103 Tahun 2015.

2. Akibat hukum perolehan hak milik atas tanah dalam perkawinan campuran dengan atau tanpa perjanjian kawin adalah tidak hapus karena hukum sepanjang dimiliki WNI. Hak milik hapus jika beralih ke WNA karena pewarisan percampuran harta dan tidak dilepaskan sebelum satu tahun. Hak milik yang dimiliki WNI dalam perkawinan campuran dengan atau tanpa perjanjian kawin dapat dialihkan kepada pihak lain atau dibebani dengan hak tanggungan tanpa perlu dibuat akta pelepasan. Dalam peralihan atau pembebanannya pencantuman identitas pasangan kawin WNA yang tertera dalam akta PPAT adalah memberikan persetujuan sehingga akta dimaksud dapat didaftarkan di BPN.

\section{Saran}

1. Kepada Notaris/PPAT agar menerapkan aturan perolehan hak milik bagi WNI dalam perkawinan campuran dengan atau tanpa perjanjian kawin. Putusan MK No. 69/PUU-XII/2015 tidak perlu dipedomani. Selanjutnya disarankan kepada

${ }^{40}$ Lihat Irma Devita Purnamasari 2014, Panduan Lengkap Hukum Praktis Populer: Kiat-kiat Cerdas, Mudah, dan Bijak Memahami Masalah Hukum Jaminan Perbankan, PT. Mizan Pustaka, Bandung (selanjutnya disebut Irma Devita Purnamasari III), h. 32-33.

${ }^{41}$ Dalam hak jaminan kebendaan terdapat asas publisitas, artinya hak kebendaan tersebut memerlukan suatu perbuatan hukum khusus yang wajib dilakukan sehingga umum atau masyarakat mengetahui keberadaan hak kebendaan yang bersangkutan. Ini penting mengingat sentralnya kedudukan hak kebendaan dalam ruang lingkup keperdataan, agar sejak dini hak tersebut tidak akan diganggu gugat oleh pihak lain. Atau sebaliknya untuk kepentingan pihak ketiga. M. Isnaeni, 2016, Hukum Jaminan Kebendaan; Eksistensi, Fungsi, dan Pengaturan, Laksbang Pressindo, Yogyakarta (selanjutnya disebut M. Isnaeni II), h. 104. 
Pemerintah agar merevisi PP No. 103 Tahun 2015 dengan menghapus ketentuan Pasal 3. Pasal 3 PP No. 103 Tahun 2015 saat ini juga sedang dilakukan uji materiil oleh Perkumpulan Masyarakat Perkawinan Campuran (PerCa) Indonesia di MA. Disarankan kepada MA agar menyatakan tidak sah Pasal tersebut.

2. Disarankan kembali kepada Notaris/PPAT agar menerapkan aturan peralihan atau pembebanan terhadap hak milik yang dimiliki WNI dalam perkawinan campuran dengan atau tanpa perjanjian kawin.

3. Kepada BPN agar mengeluarkan surat edaran yang dapat dijadikan pedoman untuk pendaftaran akta dimaksud.

4. Kepada peneliti berikutnya disarankan agar melakukan penelitian terhadap penerapan Pasal 3 PP No. 103 Tahun 2015 ataupun Putusan MK No. 69/PUUXIII/2015 dalam praktek Kenotariatan. Penelitian ini disarankan mengingat penulis telah mengemukakan WNI dalam perkawinan campuran baik dengan atau tanpa perjanjian kawin dapat memperoleh hak milik atas tanah.

Ucapan terima Kasih (Acknowledgments)

Artikel ini disarikan dan dikembangkan lebih lanjut dari Tesis yang disusun oleh penulis pada Program Studi Magister Kenotariatan Fakutas Hukum Universitas Udayana. Untuk itu, penulis mengucapkan terima kasih kepada para Pembimbing, Pimpinan, dan Staf pada program studi tersebut.

\section{DAFTAR PUSTAKA}

Buku

Adjie, H, (2014), Merajut Pemikiran Dalam Dunia Notaris \& PPAT, Cet. II, PT. Citra Aditya Bakti, Bandung.

(2016), Kompilasi Persoalan Hukum Dalam Praktek Notaris dan PPAT (Kapita Selekta Notaris \& PPAT), Jilid 1, Indonesia Notary Community (INC).

Agustina, R, (2012), "Beberapa Catatan Tentang Hukum Perkawinan di Indonesia, dalam Hukum Tentang Orang, Hukum Keluarga, dan Hukum Waris di Belanda dan Indonesia", Pustaka Larasan, Denpasar.

Ali, A, (2015), Menguak Teori Hukum (Legal Theory) dan Teori Peradilan (Jurisprudence): Termasuk Interpretasi Undang-Undang (Legisprudence) Volume 1 Pemahaman Awal, Prenadamedia Group, Jakarta.

Budiono, H, (2016), Kumpulan Tulisan Hukum Perdata di Bidang Kenotariatan: Buku Kesatu, PT. Citra Aditya Bakti, Bandung.

Damanhuri, (2012), Seg-segi Hukum Perjanjian Perkawinan Harta Bersama, Mandar Maju, Bandung.

Handoko, W, (2014), Kebijakan Hukum Pertanahan; Sebuah Refleksi Keadilan Hukum Progresif, Thafa Media, Yogyakarta.

Judiasih, S. D, (2015), Harta Benda Perkawinan, Kajian Terhadap Kesetaraan Hak dan Kedudukan Suami dan Isteri Atas Kepemilikan Harta Dalam Perkawinan, PT. Refika Aditama, Bandung. 
Indrati S., Farida M, (2007), Ilmu Perundang-undangan I: Jenis, Fungsi, dan Materi Muatan, Cet XXII, Kanisius, Yogyakarta.

(2007), Ilmu Perundang-undangan 2: Proses dan Teknik Penyusunan, Kanisius, Yogyakarta.

Isnaeni, M., (2016), Hukum Jaminan Kebendaan; Eksistensi, Fungsi, dan Pengaturan, Laksbang Pressindo, Yogyakarta.

Kelsen, Hans, (1991), General Theory of Norms, Clarendon Press, Oxford.

Kolopaking, Anita D.A., (2013), Penyelundupan Hukum Kepemilikan Hak Milik Atas Tanah di Indonesia, PT. Alumni, Bandung.

Lloyd's, (1985), Introduciton to Jusrisprudence, Stevens and Sons Ltd, London.

Melia, Djaja S., (2015), Perkembangan Hukum Perdata Tentang Orang dan Keluarga, Nuansa Aulia, Bandung.

Noor, Aslan, (2006), Konsep Hak Milik Atas Tanah Bagi Bangsa Indonesia Ditinjau Dari Ajaran Hak Asasi Manusia, CV. Mandar Maju, Bandung.

Philipus M. Hadjon dan Tatiek Sri Djatmati, (2005), Argumentasi Hukum, Gadjah Mada University Press, Yogyakarta.

Parlindungan, A.P., (2008), Komentar Atas Undang-undang Pokok Agraria, Cet. IX, CV. Mandar Maju, Bandung.

Purnamasari, I D, (2013), Kicauan Praktisi @IrmaDevitaCom: Seputar Pertanahan, PT. Mizan Pustaka, Bandung.

(2014), Panduan Lengkap Hukum Praktis Populer: Kiat-kiat Cerdas, Mudah, dan Bijak Memahami Masalah Hukum Jaminan Perbankan, PT. Mizan Pustaka, Bandung.

(2015), Panduan Lengkap Hukum Praktis Populer: Kiat-kiat Cerdas, Mudah, dan Bijak Memahami Masalah Hukum Waris, Cet. II, PT. Mizan Pustaka, Bandung

Ramelan, Eman, et. al., (2015), Problematika Hukum Hak Milik Atas Satuan Rumah Susun dalam Pembebanan dan Peralihan Hak Atas Tanah, Cet. II, Aswaja Pressindo, Yogyakarta.

(2015), Perlindungan Hukum bagi Konsumen Pembeli Satuan Rumah Susun/Strata Title/Apartemen, Aswaja Pressindo, Yogyakarta.

Roestamy, H. Martin, Konsep-konsep Hukum Properti Bagi Asing (Dihubungkan dengan Hukum Pertanahan), PT. Alumni, Bandung.

Sodiki, Achmad, (2013), Politik Hukum Agraria, Konstitusi Press (Konpress), Jakarta. 
Santoso, Urip, (2014), Hukum Agraria: Kajian Komprehensif, Cet IV, Prenadamedia Group, Jakarta.

Sumardjono, Maria S.W., (2008), Alternatif Kebijakan Pengaturan hak Atas Tanah Beserta Bangunan Bagi Warga Negara Asing dan Badan Hukum Asing, Cet. II, Kompas, Jakarta.

(2009), Tanah Dalam Perspektif Hak Ekonomi Sosial dan Budaya, Kompas, Jakarta.

Wyasa Putra, Ida Bagus, (2003), Hukum Bisnis Pariwisata, PT. Refika Aditama, Bandung. (2012), Hukum Sebagai Suatu Sistem, PT. Fikahati Aneska, Jakarta.

(2015), “Analisis Konteks dalam Epistemologi Ilmu Hukum: Suatu Model Penerapan dalam Pengaturan Perdagangan Jasa Pariwisata Internasional Indonesia", Orasi Ilmiah Pidato Pengukuhan Jabatan Guru Besar Tetap Dalam Bidang Ilmu Hukum (Hukum Ekonomi Internasional) Pada Fakultas Hukum Universitas Udayana, Jimbaran.

(2016), Teori Hukum dengan Orientasi Kebijakan (Policy-Oriented of Law): Pemecahan Problem Konteks dalam Proses Legislasi Indonesia, Udayana University Press, Denpasar.

\section{$\underline{\text { Tesis }}$}

Januartayasa, I Made, 2010, "Pelepasan Hak milik Atas Tanah Yang Diperoleh Suami Istri Dalam Perkawinan Campuran Di Kabupaten Badung", Tesis Program Studi Magister Kenotariatan, Fakultas Hukum Universitas Brawijaya, Malang.

Winarta, Eddy Nyoman, 2017, “Hak Pakai Atas Rumah Hunian Warga Negara Asing Dalam Perkawinan Campuran", Tesis Program Magister Kenotariatan, Fakultas Hukum Universitas Udayana, Denpasar.

Yudhianto Putro, Herri, 2013, “Kewenangan Bertindak Warga Negara Indonesia Dalam Perkawinan Campuran Atas Kepemilikan Hak Milik Atas Tanah", Tesis Program Studi Magister Kenotariatan, Fakultas Hukum Universitas Diponegoro, Semarang.

\section{$\underline{\text { Makalah }}$}

Alwesius, "Pembuatan Akta Perjanjian Perkawinan Pasca Putusan Mahkamah Konstitusi Nomor 69/PUU-XIII/2015 Serta Akibat Hukumnya Terhadap Perolehan, Penjaminan, dan Kepemilikan Tanah Oleh Pasangan Kawin Campur", Makalah Pada Seminar Terbatas Dengan Tema: Implementasi Putusan Mahkamah Konstitusi Tentang Perkawinan Campur, Kaitannya dengan Pemilikan Properti di Indonesia dan Praktek Notaris-PPAT, Diselenggarakan Oleh Pengurus Wilayah Ikatan Notaris Indonesia (INI) dan Ikatan Pejabat Pembuat Akta Tanah (IPPAT) Bali, Denpasar.

Hernoko, Agus Yudha, 2016, “Quo Vadis Perlindungan Hukum Bagi Pihak Ketiga Dalam Perjanjian Perkawinan (Problematika Hukum Pasca Putusan MK Nomor 
69/PUU-XIII/2015)", Makalah Pada Seminar: Problematika Perjanjian Kawin Pasca Putusan Mahkamah Konstitusi No. 69/PUU-XIII/2015, Program Studi Magister Kenotariatan, Fakultas Hukum Universitas Airlangga, Surabaya.

Isnaeni, M., 2016, "Problematika Perjanjian Kawin Pasca Putusan Mahkamah Konstitusi No. 69/PUU-XIII/2015", Makalah Pada Seminar: Problematika Perjanjian Kawin Pasca Putusan Mahkamah Konstitusi No. 69/PUU-XIII/2015, Program Studi Magister Kenotariatan, Fakultas Hukum Universitas Airlangga, Surabaya.

Palguna, I Dewa Gede, 2016, “Perkawinan Campuran dan Pemilikan Hak Atas Tanah Pasca-Putusan Mahkamah Konstitusi Nomor 69/PUU-XIII/2015", Makalah Pada Seminar Terbatas Dengan Tema: Implementasi Putusan Mahkamah Konstitusi tentang Perkawinan Campur, Kaitannya Dengan Pemilikan Properti di Indonesia dan Praktek Notaris-PPAT, Diselenggarakan Oleh Pengurus Wilayah Ikatan Notaris Indonesia (INI) dan Ikatan Pejabat Pembuat Akta Tanah (IPPAT) Bali, Denpasar.

Rachmi Handayani, I Gusti Ayu Ketut, 2017, "Kewarganegaraan dan Warisan Pada Perkawinan Campuran", Makalah Pada Seminar: Keragaman Hukum Waris Di Indonesia, Problematika Dan Solusinya Dalam Pembuatan Surat/Akta Keterangan Hak Waris, Diselenggarakan Oleh Pengurus Daerah Ikatan Notaris Indonesia (INI) Sukoharjo dengan "Pioneer" Study Club Notary dan didukung oleh Fakultas Hukum Universitas Sebelas Maret Surakarta, Sukoharjo.

Wyasa Putra, Ida Bagus, 2016, “Perjanjian Kawin Dalam Perkawinan Campuran Paska Putusa MK No. 69/PUU-XIII/2015", Makalah Pada: Konfrensi Pengurus Daerah (Konferda) Ikatan Notaris Indonesia (INI) Badung, Bali.

\section{Artikel}

Hukum Online.com, 2016, "PP Hunian Orang Asing: MA Diminta Batalkan Klausula 'Perjanjian Kawin'”, Published on 10-10-2016, diakses pada tanggal 13-03-2017 melalui media resmi akun jejaring sosial twitter, available from: URL:http:// www.hukumonline.com/berita/baca/lt5823c5d6a4f6a/madiminta-batalkan-klausula-perjanjian-kawin.html.

Swandewi, Ida Ayu Putu, 2016, "Pengesahan Akta Notaris Bagi Penghadap Yang Mengalami Cacat Fisik" Majalah Acta Comitas Jurnal Hukum Kenotariatan Magister Kenotariatan Universitas Udayana Volume I Nomor 1, April 2016.

\section{Peraturan Perundang-undangan}

Undang-Undang Dasar Negara Republik Indonesia Tahun 1945. Burgerlijk Wetboek, Staatsblad 1847-23, terjemahan R. Subekti dan R. Tjitrosudibio, Pradnya Paramita, Jakarta. 
Undang-Undang Republik Indonesia Nomor 5 Tahun 1960 Tentang Peraturan Dasar Pokok-Pokok Agraria, Lembaran Negara Republik Indonesia Nomor 1960 104, Tambahan Lembaran Negara Republik Indonesia Nomor 2043.

Undang-Undang Republik Indonesia Nomor 1 Tahun 1974 Tentang Perkawinan, Lembaran Negara Republik Indonesia Nomor 1, Tambahan Lembaran Negara Republik Indonesia Nomor 3019.

Undang-Undang Republik Indonesia Nomor 4 Tahun 1996 Tentang Hak Tanggungan atas Tanah Beserta Benda-benda yang Berkaitan dengan Tanah, Lembaran Negara Republik Indonesia Tahun 1996 Nomor 42, Tambahan Lembaran Negara Republik Indonesia Nomor 3632.

Undang-Undang Republik Indonesia Nomor 5 Tahun 2004 Tentang Perubahan Atas Undang-Undang Nomor 14 Tahun 1985 Tentang Mahkamah Agung, Lembaran Negara Republik Indonesia Tahun 2004 Nomor 9, Tambahan Lembaran Negara Republik Indonesia Nomor 4359.

Undang-Undang Republik Indonesia Nomor 12 Tahun 2006 Tentang Kewarganegaraan, Lembaran Negara Republik Indonesia Tahun 2006 Nomor 63, Tambahan Lembaran Negara Republik Indonesia Nomor 4634.

Undang-Undang Republik Indonesia Nomor 1 Tahun 2011 Tentang Perumahan Dan Kawasan Pemukiman, Lembaran Negara Republik Indonesia Tahun 2011 Nomor 7, Tambahan Lembaran Negara Republik Indonesia Nomor 5188.

Undang-UndangRepublik Indonesia Nomor 12 Tahun 2011 Tentang Pembentukan Peraturan Perundang-undangan, Lembaran Negara Republik Indonesia Tahun 2011 Nomor 82, Tambahan Lembaran Negara Republik Indonesia Nomor 5234.

Undang-Undang Republik Indonesia Nomor 20 Tahun 2011 Tentang Rumah Susun, Lembaran Negara Republik Indonesia Tahun 2011 Nomor 108, Tambahan Lembaran Negara Republik Indonesia Nomor 5252.

Undang-Undang Republik Indonesia Nomor 2 Tahun 2014 Tentang Perubahan Atas Undang-undang Nomor 30 Tahun 2004 Tentang Jabatan Notaris, Lembaran Negara Republik Indonesia Tahun 2014 Nomor 3, Tambahan Lembaran Negara Republik Indonesia Nomor 5491.

Peraturan Pemerintah Republik Indonesia Nomor 103 Tahun 2015 Tentang Pemilikan Rumah Tempat Tinggal Atau Hunian Oleh Orang Asing Yang Berkedudukan Di Indonesia, Lembaran Negara Republik Indonesia Tahun 2015 Nomor 325, Tambahan Lembaran Negara Republik Indonesia Nomor 5793.

Putusan Mahkamah Konstitusi Republik Indonesia Nomor 69/PUU-XIII/2015, Tertanggal 27-10-2016. 